\title{
Enhancing of Users' Satisfaction with Circulation Policies in Public University Libraries in Nigeria
}

\author{
Umbur Demekaa', Nicholas Mfangu Tyonum² ${ }^{2}$ and Bridget Demekaa ${ }^{3}$ \\ ${ }^{1}$ University Library, Benue State University, Makurdi- Nigeria \\ ${ }^{2}$ Department of Library and Information Science, Benue State University, Makurdi- Nigeria \\ ${ }^{3}$ University Library, Benue State University, Makurdi- Nigeria \\ E-mail: tyonik@yahoo.com
}

\begin{abstract}
The purpose of this study is to determine the enhancement of users' level of satisfaction with circulation policies in public university libraries in Nigeria. A descriptive survey was adopted for the study. The population comprised all the undergraduate registered users of the university libraries in North Central Zone of Nigeria. The stratified random sampling technique was used to draw a sample of 600 registered library users for the study from four university libraries of which, $\mathbf{5 6 2}$ were retrieved from the users who were in the library. A total of seven research questions were raised and seven hypotheses formulated to guide the study. A self constructed questionnaire entitled; "Enhancing of Users' Satisfaction with Circulation Policies in Public University Libraries in Nigeria Questionnaire” (EUSCPPULNQ) was the instrument used for the data collection. The data collected were analysed by using mean and standard deviation to answer the research questions, while z-test statistical technique was to test the formulated hypotheses at 0.05 level of significance. Findings revealed that Federal universities had moderate mean in the level of satisfaction with library opening hours than State owned universities; The study also revealed that there was no significant difference between Federal and State universities in users' level of satisfaction with library holdings, borrowers' cards, loan periods, fines and reservation. There was no significant difference between Federal and State owned universities except in user's level of satisfaction with library opening hours. Finally, it was recommended that public university libraries in Nigeria should extend their opening hours on Sundays to make the users more satisfied with opening hours on that day.

Keywords: Users' Satisfaction, Circulation policies, Public University Libraries, Nigeria
\end{abstract}

\section{I.INTRODUCTION}

The holdings of any library are intended to meet the information needs of library users and to make effective use of them based on the vision and mission of the institution concerned (Demekaa, 2015). Libraries all over the world are faced with daunting challenges in the course of their operations. Among those challenges is finding the right number of hours during which the library is available to users. Steele (2001) notes that consumers have different values to which we must respond: convenience, timeliness, cost effectiveness, and speed. For libraries, customer values are expressed in demands for hours that meet individual needs for timely, and indeed, non-traditional access to facilities and services. As a result, university libraries are studying library hours more regularly and closely than they have in the past to determine where changes need to be made to meet demands, (SPEC 2001).

Lamptey (2010) confirms that materials in circulation section may be lent out to registered users of the library who have officially been given borrowers' cards or registered with the library. The loan period for undergraduate students shows five (5) number of books, for period of two (2) weeks to return them. Al-Fares (1998) sees user satisfaction as a common objective based on all the literature surveyed. For measuring satisfaction, most articles simply choose immediate availability- the probability of finding a required book available on the shelf. Variations include availability of the most popular books, satisfaction with the loan period and the waiting time, and some cost-based on objectives.

Adomi (2003) reveals the feelings of respondents that overdue fines are to compel users to return borrowed books on time. One of the reasons that overdue fines are introduced in libraries is to force library users to return the materials they have borrowed on time, so that other users can have access to them. The term reserve book collection refers to any collection of books and other materials that are set aside for the use of mostly undergraduates students and distinctly housed in a special area within a university library designated for that particular purpose (Agboola, 2000). Also, Gates (1989) sees reserve materials as those in which class assignments have made. They are kept together in one location and administered under special rules and regulations. The rules that apply to their administration and use are different from the ones that apply to the use of open access collections. Reserve book collections are often referred to as short term loan collection or limited loan collection and are administered under a library service called reserve book service or short loan service or limited loan service.

\section{II.STATEMENT OF THE PROBLEM}

Preliminary observations showed that some users do not like to return borrowed materials when due. Some do not 
like to pay overdue fines. There are also those who complain about inadequate materials held by libraries; there are also users who complain about the types of materials on reservation as well as the length of time reserved materials are allowed on loan. Could these be evidences of general lack of satisfaction with library circulation policies?

This study has therefore set out to explore users' levels of satisfaction with circulation policies in public university libraries in Nigeria.

\section{III.RESEARCH QUESTIONS}

The study sought answers to the following research questions:

i) What is the level of library users' satisfaction in federal and state universities regarding circulation policies in public university libraries in North Central Zone of Nigeria?

ii) What is the level of library users' satisfaction in public universities regarding circulation policy on: library holdings; library opening hours; library borrowers' cards; library loan periods; library fines and library reservation?

\section{Research Hypotheses}

The following hypotheses were tested in the study:

i) There is no significant difference between public universities in the library users' levels of satisfaction with circulation policies in university libraries in Nigeria. ii) There is no significant difference between public universities in the library users' levels of satisfaction with circulation policy on library holdings; library opening hours; library borrowers' cards; library loan periods; library fines and library reservation.

\section{IV.METHODOLOGY}

This study is a descriptive survey research and therefore employed the descriptive survey design. A total of 600 copies of the questionnaire were administered personally by the researchers and with the help of some research assistants, to the users' of the various public university libraries under study. Out of which, 562 were retrieved from the users' who were in the libraries to use their services.

The data obtained from the questionnaire were analysed using frequency counts, mean and standard deviation to answer the research questions and z-test statistical technique was used to test the formulated hypotheses. The levels of satisfaction from $4.00-3.50$ were rated as high, while 3.49 -2.50 as moderate and $2.49-1.00$ as low. It was used here because the study involved the comparison of two groups (federal and state universities) and the sample size was large, (Onwioduokit, 2001).

\section{V.DATA ANALYSIS AND DISCUSSION}

Research Question One: What is the level of library users' satisfaction in public universities regarding circulation policies in the university libraries in Nigeria?

TABLEI MEAN AND STANDARD DEVIATION OF USER'S SATISFACTION WITH LIBRARY CIRCULATION POLICIES IN NIGERIA UNIVERSITIES

\begin{tabular}{|c|c|c|c|c|c|c|}
\hline Components & $\mathrm{S} / \mathbf{N}$ & Items & $\mathbf{N}$ & $\overline{\bar{X}}$ & SD & Satisfaction Level \\
\hline \multirow{5}{*}{ 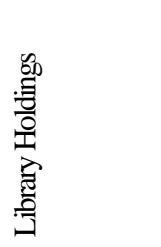 } & 1. & Open circulation materials & 562 & 3.48 & .68 & Moderate \\
\hline & 2. & Materials not allowed on loan & 562 & 3.09 & 68 & Moderate \\
\hline & 3. & Available circulatory materials & 562 & 2.95 & .78 & Moderate \\
\hline & 4. & Materials not allowed in Closed access & 562 & 3.04 & .85 & Moderate \\
\hline & 5. & Maximum borrowing opportunity & 562 & 3.19 & .80 & Moderate \\
\hline \multirow{6}{*}{ 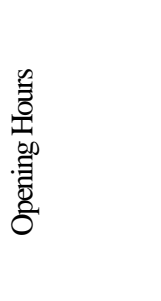 } & 1. & Weekly Opening hours & 562 & 3.30 & 67 & Moderate \\
\hline & 2. & Saturday opening hours & 562 & 3.17 & .77 & Moderate \\
\hline & 3. & Sunday opening hours & 562 & 2.89 & .85 & Moderate \\
\hline & 4. & Public holiday opening hours & 562 & 2.95 & .85 & Moderate \\
\hline & 5. & Examination period opening hours & 562 & 3.06 & .80 & Moderate \\
\hline & 6. & Vacations period opening hours & 562 & 3.11 & .79 & Moderate \\
\hline \multirow{4}{*}{ 気 } & 1. & Number of registered cards for borrowing & 562 & 3.48 & .68 & Moderate \\
\hline & 2. & Process of cards obtainable & 562 & 3.09 & .68 & Moderate \\
\hline & 3. & Financial cost of borrowers' cards & 562 & 2.95 & .78 & Moderate \\
\hline & 4. & Financial cost of lost cards & 562 & 3.04 & .85 & Moderate \\
\hline
\end{tabular}




\begin{tabular}{|c|c|c|c|c|c|c|}
\hline Components & $\mathrm{S} / \mathbf{N}$ & Items & $\mathbf{N}$ & $\overline{\bar{X}}$ & SD & Satisfaction Level \\
\hline & 5. & Process of card replacement & 562 & 3.19 & .80 & Moderate \\
\hline \multirow{10}{*}{ 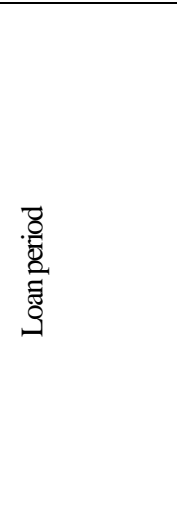 } & 1. & Duration of material borrowing & 562 & 3.29 & .62 & Moderate \\
\hline & 2. & Reserved materials borrowing period within the library & 562 & 3.23 & .72 & Moderate \\
\hline & 3. & Duration of reserved materials allowed for home use & 562 & 3.04 & .75 & Moderate \\
\hline & 4. & Duration of project borrowing within the library & 562 & 3.05 & .78 & Moderate \\
\hline & 5. & Frequency of item renewal & 562 & 3.11 & .71 & Moderate \\
\hline & 6. & Channels of Patron renewal & 562 & 3.24 & .74 & Moderate \\
\hline & 7. & Procedure for renewing borrowed items & 562 & 3.16 & .70 & Moderate \\
\hline & 8. & Holding policy of borrowed items at circulation desk & 562 & 3.03 & .75 & Moderate \\
\hline & 9. & Recalling policy before expiration & 562 & 3.12 & .80 & Moderate \\
\hline & 10. & Notification policy of held items & 562 & 3.16 & .75 & Moderate \\
\hline \multirow{4}{*}{ 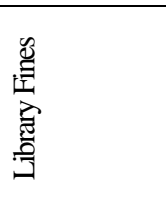 } & 1. & Fine for overdue books/materials & 562 & 3.14 & .71 & Moderate \\
\hline & 2. & Fine paid for lost items & 562 & 3.19 & .76 & Moderate \\
\hline & 3. & Fine for damaged items & 562 & 3.07 & .82 & Moderate \\
\hline & 4. & Borrower's financial liability for lost materials & 562 & 3.15 & .80 & Moderate \\
\hline \multirow{5}{*}{ 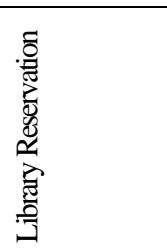 } & 1. & The location of the research section & 562 & 3.46 & .74 & Moderate \\
\hline & 2. & Borrowing of reserved items & 562 & 3.10 & .68 & Moderate \\
\hline & 3. & Number of borrowed reserved books & 562 & 3.07 & .87 & Moderate \\
\hline & 4. & The duration of borrowing books on reservation & 562 & 3.11 & .81 & Moderate \\
\hline & 5. & The way reserved materials are recorded & 562 & 3.25 & .81 & Moderate \\
\hline
\end{tabular}

Table I with respect to holdings, the mean for respondents' level of satisfaction is highest for types of materials that are allowed on loan ( $\overline{\mathrm{X}}$ 3.48). The opening hours also attracted the highest mean scores of 3.30 of all the six items. The majority of the respondents were very satisfied with the items on borrowers' cards. The users were however, satisfied with circulation policy on loan period, with all the ten items. The table also shows that circulation policies on fines and reservation, indicated respondents level of satisfaction. This finding collaborates that by Senevirante (2006) whose respondents were satisfied with book reservation.

Research Question Two: What is the level of library users' satisfaction in public universities regarding circulation policy on library holdings?

TABLE II MEAN AND STANDARD DEVIATION OF USERS' SATISFACTION WITH LIBRARY HOLDINGS IN PUBLIC UNIVERSITIES

\begin{tabular}{|c|c|c|c|c|c|c|}
\hline $\mathbf{S} / \mathbf{N}$ & Items & Type of Institution & $\mathbf{N}$ & $\bar{X}$ & SD & $\begin{array}{c}\text { Satisfaction } \\
\text { level }\end{array}$ \\
\hline \multirow{2}{*}{1.} & \multirow[t]{2}{*}{ Open circulation materials } & Federal & 336 & 3.52 & .67 & High \\
\hline & & State & 226 & 3.42 & .67 & Moderate \\
\hline \multirow{2}{*}{2.} & \multirow[t]{2}{*}{ Materials not allowed on loan } & Federal & 336 & 3.10 & .65 & Moderate \\
\hline & & State & 226 & 3.09 & .71 & Moderate \\
\hline \multirow{2}{*}{3.} & \multirow{2}{*}{ Available circulatory Materials } & Federal & 336 & 2.90 & .78 & Moderate \\
\hline & & State & 226 & 3.06 & .77 & Moderate \\
\hline \multirow{2}{*}{4.} & \multirow{2}{*}{$\begin{array}{l}\text { Materials not allowed in Closed } \\
\text { access }\end{array}$} & Federal & 336 & 3.00 & .90 & Moderate \\
\hline & & State & 226 & 3.10 & .75 & Moderate \\
\hline \multirow{2}{*}{5.} & \multirow{2}{*}{$\begin{array}{l}\text { Maximum borrowing } \\
\text { opportunity }\end{array}$} & Federal & 336 & 3.12 & .84 & Moderate \\
\hline & & State & 226 & 3.30 & .72 & Moderate \\
\hline
\end{tabular}


Table II indicates the mean and standard deviation of users' level of satisfaction with library holdings by the undergraduates. From the table, the types of materials that are allowed on loan attracted the high mean of 3.52 in federal universities and with moderate mean score of 3.42 in state universities. These finding corroborate that of Seneviratne (2006) who measured users' satisfaction with the Postgraduate Institute of Medicine Branch Library,
Teaching Hospital, Peradeniya, and found that a majority of the users were satisfied or very satisfied with the quality of textbook collection, and that overall satisfaction levels were for the quality of library holdings.

Research Question Three: What is the level of library users' satisfaction in public universities regarding circulation policy on library opening hours?

TABLE III MEAN AND STANDARD DEVIATION OF USER'S SATISFACTION WITH LIBRARY OPENING HOURS IN PUBLIC UNIVERSITIES

\begin{tabular}{|c|c|c|c|c|c|c|}
\hline $\mathrm{S} / \mathbf{N}$ & Items & $\begin{array}{l}\text { Type of } \\
\text { Institution }\end{array}$ & $\mathbf{N}$ & $\bar{X}$ & SD & $\begin{array}{c}\text { Satisfaction } \\
\text { level }\end{array}$ \\
\hline \multirow[b]{2}{*}{1.} & \multirow[t]{2}{*}{ Weekly Opening hours } & Federal & 336 & 3.33 & .65 & Moderate \\
\hline & & State & 226 & 3.25 & .66 & Moderate \\
\hline \multirow{2}{*}{2.} & \multirow[t]{2}{*}{ Saturday opening hours } & Federal & 336 & 3.22 & .75 & Moderate \\
\hline & & State & 226 & 3.07 & .79 & Moderate \\
\hline \multirow{2}{*}{3.} & \multirow[t]{2}{*}{ Sunday opening hours } & Federal & 336 & 2.87 & .86 & Moderate \\
\hline & & State & 226 & 2.89 & .83 & Moderate \\
\hline \multirow{2}{*}{4.} & \multirow[t]{2}{*}{ Public holiday opening hours } & Federal & 336 & 3.00 & .88 & Moderate \\
\hline & & State & 226 & 2.66 & .80 & Moderate \\
\hline \multirow{2}{*}{5.} & \multirow{2}{*}{$\begin{array}{l}\text { Examination period opening } \\
\text { hours }\end{array}$} & Federal & 336 & 3.07 & .79 & Moderate \\
\hline & & State & 226 & 3.03 & .81 & Moderate \\
\hline \multirow{2}{*}{6.} & \multirow{2}{*}{$\begin{array}{l}\text { Vacation period opening } \\
\text { hours }\end{array}$} & Federal & 336 & 3.14 & .79 & Moderate \\
\hline & & State & 226 & 3.06 & .77 & Moderate \\
\hline
\end{tabular}

Table III reveals the users' level of satisfaction with library opening hours. From the table, library opening hours on week days (Monday-Friday) attracted the moderate mean for federal $(\overline{\mathrm{X}}=3.33$; $\mathrm{SD}=.65)$ and state $(\overline{\mathrm{X}}=3.25 ; \mathrm{SD}=.66)$ Universities - with .8 mean difference in favour of the former. On week days (Monday-Friday) university libraries in the North Central Zone of Nigeria operate from $8.00 \mathrm{am}$ to $10.00 \mathrm{pm}$. The opening hours are satisfactory to the student users of the federal and state university libraries surveyed. This finding corroborates that by Seneviratne (2006) in which the majority of the users of the Postgraduate Institute of Medicine Branch Library, at Peradeniya were satisfied with the opening hours on week days.

Research Question Four: What is the level of library users' satisfaction in public universities regarding circulation policy on library borrowers' cards?

TABLE IV MEAN AND STANDARD DEVIATION OF USERS’ SATISFACTION WITH LIBRARY BORROWERS’ CARDS IN PUBLIC UNIVERSITIES

\begin{tabular}{|c|c|c|c|c|c|c|}
\hline $\mathbf{S} / \mathbf{N}$ & Items & $\begin{array}{l}\text { Type of } \\
\text { Institution }\end{array}$ & $\mathbf{N}$ & $\mathrm{X}$ & SD & $\begin{array}{c}\text { Satisfaction } \\
\text { Level }\end{array}$ \\
\hline \multirow{2}{*}{1.} & \multirow{2}{*}{$\begin{array}{l}\text { Number of registered cards for } \\
\text { borrowing }\end{array}$} & Federal & 336 & 3.53 & .61 & High \\
\hline & & State & 226 & 3.34 & .67 & Moderate \\
\hline \multirow{2}{*}{2.} & \multirow[t]{2}{*}{ Process of cards obtainable } & Federal & 336 & 3.11 & .66 & Moderate \\
\hline & & State & 226 & 3.16 & .66 & Moderate \\
\hline \multirow{2}{*}{3.} & \multirow{2}{*}{$\begin{array}{l}\text { Financial cost of borrowers' } \\
\text { cards }\end{array}$} & Federal & 336 & 3.12 & .77 & Moderate \\
\hline & & State & 226 & 3.12 & .69 & Moderate \\
\hline \multirow{2}{*}{4.} & \multirow[t]{2}{*}{ Financial cost of lost cards } & Federal & 336 & 2.97 & .85 & Moderate \\
\hline & & State & 226 & 3.11 & .73 & Moderate \\
\hline \multirow{2}{*}{5.} & \multirow[t]{2}{*}{ Process of card replacement } & Federal & 336 & 3.03 & .79 & Moderate \\
\hline & & State & 226 & 3.08 & .70 & Moderate \\
\hline
\end{tabular}


Table IV shows the means and standard deviations of users' level of satisfaction with the borrowers' cards by undergraduate library users in the North Central Zone. As can be seen in the table, users' level of satisfaction with the total number of cards they are issued for borrowing books attracted a high mean of 3.53 in federal universities and a moderate mean of 3.34 in state universities, though the mean score of the former is higher. The maximum number of borrowers' cards students are expected to be issued are spelt out in the library circulation policy (Adomi, 2008).

Research Question Five: What is the level of library users' satisfaction in public universities regarding circulation policy on loan periods?

TABLE V MEAN AND STANDARD DEVIATION OF USERS' SATISFACTION WITH LIBRARY LOAN PERIODS IN PUBLIC UNIVERSITIES

\begin{tabular}{|c|c|c|c|c|c|c|}
\hline $\mathbf{S} / \mathbf{N}$ & Items & $\begin{array}{c}\text { Type of } \\
\text { Institution }\end{array}$ & $\mathbf{N}$ & $\bar{X}$ & SD & $\begin{array}{c}\text { Satisfaction } \\
\text { level }\end{array}$ \\
\hline \multirow{2}{*}{1.} & \multirow[t]{2}{*}{ Duration of borrowing materials } & Federal & 336 & 3.28 & .63 & Moderate \\
\hline & & State & 226 & 3.29 & .59 & Moderate \\
\hline \multirow{2}{*}{2.} & \multirow{2}{*}{$\begin{array}{l}\text { Reserved materials borrowing } \\
\text { period within the library }\end{array}$} & Federal & 336 & 3.24 & .74 & Moderate \\
\hline & & State & 226 & 3.21 & .67 & Moderate \\
\hline \multirow{2}{*}{3.} & \multirow{2}{*}{$\begin{array}{l}\text { Duration reserved materials are } \\
\text { allowed for home use }\end{array}$} & Federal & 336 & 3.01 & .76 & Moderate \\
\hline & & State & 225 & 3.07 & .72 & Moderate \\
\hline \multirow[b]{2}{*}{4.} & \multirow{2}{*}{$\begin{array}{l}\text { Duration of project borrowing } \\
\text { within the library }\end{array}$} & Federal & 336 & 3.03 & .82 & Moderate \\
\hline & & State & 226 & 3.05 & .71 & Moderate \\
\hline \multirow{2}{*}{5.} & \multirow[t]{2}{*}{ Frequency of item renewal } & Federal & 336 & 3.10 & .75 & Moderate \\
\hline & & State & 226 & 3.11 & .75 & Moderate \\
\hline \multirow{2}{*}{6.} & \multirow{2}{*}{ Channels of patron renewal } & Federal & 336 & 3.26 & .72 & Moderate \\
\hline & & State & 226 & 3.19 & .75 & Moderate \\
\hline \multirow{2}{*}{7.} & \multirow{2}{*}{$\begin{array}{l}\text { Procedure for renewing borrowed } \\
\text { items }\end{array}$} & Federal & 336 & 3.13 & .72 & Moderate \\
\hline & & State & 226 & 3.19 & .75 & Moderate \\
\hline \multirow[t]{2}{*}{8.} & \multirow{2}{*}{$\begin{array}{l}\text { Holding policy of borrowed items } \\
\text { at circulation desk }\end{array}$} & Federal & 336 & 2.97 & .76 & Moderate \\
\hline & & State & 226 & 3.11 & .72 & Moderate \\
\hline \multirow{2}{*}{9.} & \multirow[t]{2}{*}{ Recalling policy before expiration } & Federal & 336 & 3.10 & .81 & Moderate \\
\hline & & State & 226 & 3.15 & .77 & Moderate \\
\hline \multirow{2}{*}{10.} & \multirow{2}{*}{ Notification policy of held items } & Federal & 336 & 3.15 & .75 & Moderate \\
\hline & & State & 226 & 3.18 & .73 & Moderate \\
\hline
\end{tabular}

TABLE VI MEANS AND STANDARD DEVIATION OF USERS' SATISFACTION WITH LIBRARY FINES IN PUBLIC UNIVERSITIES

\begin{tabular}{|c|c|c|c|c|c|c|c|}
\hline $\mathrm{S} / \mathbf{N}$ & Items & $\begin{array}{c}\text { Type of } \\
\text { Institution }\end{array}$ & $\mathbf{N}$ & $\Sigma_{\mathbf{X}}$ & $\bar{X}$ & SD & Satisfaction Level \\
\hline \multirow{2}{*}{1.} & \multirow{2}{*}{$\begin{array}{l}\text { Fine for overdue books/ } \\
\text { materials }\end{array}$} & Federal & 336 & 1150 & 3.40 & .72 & Moderate \\
\hline & & State & 226 & 766 & 3.30 & .69 & Moderate \\
\hline \multirow{2}{*}{2.} & \multirow{2}{*}{ Fine paid for lost items } & Federal & 336 & 1064 & 3.10 & .77 & Moderate \\
\hline & & State & 226 & 728 & 3.20 & .73 & Moderate \\
\hline \multirow{2}{*}{3.} & \multirow{2}{*}{ Fine for damaged items } & Federal & 336 & 1027 & 3.00 & .83 & Moderate \\
\hline & & State & 226 & 728 & 3.20 & .73 & Moderate \\
\hline \multirow{2}{*}{4.} & \multirow{2}{*}{$\begin{array}{l}\text { Borrower's financial liability } \\
\text { for } \\
\text { lost materials }\end{array}$} & Federal & 336 & 1054 & 3.10 & .81 & Moderate \\
\hline & & State & 226 & 699 & 3.00 & .79 & Moderate \\
\hline
\end{tabular}

Table $\mathrm{V}$ shows the means and standard deviations of users' level of satisfaction with library loan periods by undergraduate library users. Time/duration of library materials are allowed on loan attracted the moderate mean for federal (3.28) and state (3.29) universities with the latter slightly higher than the former. This finding corroborates 
Ezeala and Yusuf (2011) study in which users of Nigerian agricultural research institute libraries were satisfied with duration of book loan period. The purpose of book loan duration in libraries is to ensure that borrowed materials are returned on due date so that they can be available for the use of other library users. Thus the respondents in this study would like other users to have access to materials when due for return.

Research Question Six: What is the level of library users' satisfaction in public universities regarding circulation policy on library fines?

Table 1.6 shows the means and standard deviations of users' level of satisfaction with library fines by undergraduate library users. Libraries charge fines for information resources that are lost, mutilated, stolen and kept beyond due date. These fines are meant not only to generate fund for libraries but to also serve as deterrent for users who take library rules for granted (NinaOkposung, 2011).

The data in table 1.6 revealed the moderate mean of 3.4 for the federal universities respondents' level of satisfaction with the amount which defaulting users pay for overdue books/materials, slightly lower (but moderate) than the mean of 3.3 for state universities. The respondents' high level of satisfaction with overdue fines could be due to low amount libraries charge as overdue fines. Low amount encourage users to keep important materials beyond due date (Adomi, 2003; Nwalo, 2003; NinaOkposung, 2011). The finding of this study corroborate Adomi (2003) who found that some users of Delta State University were satisfied with fines because they force users to return borrowed items promptly.

Research Question Seven: What is the level of library users' satisfaction in public universities regarding circulation policy on library reservation?

TABLE VII MEAN AND STANDARD DEVIATION OF USERS' SATISFACTION WITH LIBRARY RESERVATION PRACTICES IN PUBLIC UNIVERSITIES

\begin{tabular}{|c|c|c|c|c|c|c|c|}
\hline $\mathbf{S} / \mathbf{N}$ & Items & $\begin{array}{c}\text { Type of } \\
\text { Institution }\end{array}$ & $\mathbf{N}$ & $\Sigma_{\mathbf{X}}$ & $\bar{X}$ & SD & $\begin{array}{c}\text { Satisfaction } \\
\text { Level }\end{array}$ \\
\hline \multirow{2}{*}{1.} & \multirow{2}{*}{ The location of the research section } & Federal & 336 & 1192 & 3.50 & .66 & High \\
\hline & & State & 226 & 750 & 3.30 & .66 & Moderate \\
\hline \multirow{2}{*}{2.} & \multirow{2}{*}{ Borrowing of reserved items } & Federal & 336 & 1036 & 3.00 & .68 & Moderate \\
\hline & & State & 226 & 708 & 3.10 & .67 & Moderate \\
\hline \multirow{2}{*}{3.} & \multirow{2}{*}{ Number of borrowed reserved books } & Federal & 336 & 1022 & 3.00 & .88 & Moderate \\
\hline & & State & 226 & 701 & 3.10 & .83 & Moderate \\
\hline \multirow{2}{*}{4.} & \multirow{2}{*}{$\begin{array}{l}\text { The duration of borrowing books on } \\
\text { reservation }\end{array}$} & Federal & 336 & 1037 & 3.00 & .76 & Moderate \\
\hline & & State & 226 & 709 & 3.10 & .76 & Moderate \\
\hline \multirow{2}{*}{5.} & \multirow{2}{*}{$\begin{array}{l}\text { The way reserved materials are } \\
\text { recorded }\end{array}$} & Federal & 336 & 1007 & 3.20 & .84 & Moderate \\
\hline & & State & 226 & 730 & 3.20 & .77 & Moderate \\
\hline
\end{tabular}

Table VII shows the means and standard deviations of users' level of satisfaction with the library reservation by undergraduate library users. Reserve materials are resources, collection of books and other information item that are set aside for the use of mostly undergraduate students and distinctly housed within a university library building designated for that purpose (Agboola, 2000). These materials and their use are normally regulated by policy. A majority of the respondents are satisfied with the location of the reserve section as can be seen in the moderate mean of 3.5 (federal universities) and 3.3 (state universities).

This finding corroborates that by Seneviratne (2006) in which majority of his respondents were satisfied with book reservation at Postgraduate Institute of Medicine Branch Library, Teaching Hospital, Peradeniya.

Hypothesis One: There is no significant difference between public universities in the library users' levels of satisfaction with circulation policies in university libraries.

The data in table VIII shows that there is no significant difference between federal and state universities in users' level of satisfaction with library circulation policies on holdings, library borrowers' cards, library loan periods, library fines and library reservation. This finding is in line with Demekaa (2015) and Sacchelti (2011) which found that student users were satisfied with books in the collection because they were useful.

The data generally indicate moderate users' level of satisfaction with the opening hours of the various university libraries. This finding corroborates that of Senevirantne (2006) in which majority of the users at the Postgraduate Institute of Medicine Branch Library at Peradeniya were satisfied with the opening hours on week days.

The respondents in the study were satisfied with the policy on borrowers' cards, authors such as Lamptey (2010) and Ross (2011) have reported similarly. Also, the users' were satisfied with the policy on loan periods, which also corroborates that by Ezeala and Yusuf (2011) in which respondents were satisfied with loan periods. 
TABLE VIII Z-TEST ANALYSIS OF OWNERSHIP OF UNIVERSITIES ON USERS’ LEVEL OF SATISFACTION WITH CIRCULATION POLICIES IN UNIVERSITY LIBRARIES

\begin{tabular}{|c|c|c|c|c|c|c|c|c|c|}
\hline Components & Institution & $\mathbf{N}$ & $\bar{X}$ & SD & Df & $\begin{array}{c}\text { z_calculated } \\
\text { value }\end{array}$ & $\begin{array}{c}\text { z_critical } \\
\text { value }\end{array}$ & \begin{tabular}{|c|} 
Level of \\
significance
\end{tabular} & Remark \\
\hline \multirow{2}{*}{ Holdings } & Federal & 336 & 15.95 & 2.19 & \multirow[b]{2}{*}{560} & \multirow[b]{2}{*}{1.79} & \multirow[b]{2}{*}{1.96} & \multirow[b]{2}{*}{0.05} & \multirow{2}{*}{$\begin{array}{l}\text { Retain null } \\
\text { hypothesis }\end{array}$} \\
\hline & State & 226 & 15.61 & 2.18 & & & & & \\
\hline \multirow{2}{*}{ Opening Hours } & Federal & 336 & 18.67 & 2.45 & \multirow[b]{2}{*}{560} & \multirow[b]{2}{*}{-2.15} & \multirow[b]{2}{*}{1.96} & \multirow[b]{2}{*}{0.05} & \multirow{2}{*}{$\begin{array}{l}\text { Reject null } \\
\text { hypothesis }\end{array}$} \\
\hline & State & 226 & 18.20 & 2.58 & & & & & \\
\hline \multirow{2}{*}{ Borrowers' Cards } & Federal & 336 & 15.84 & 1.90 & \multirow[b]{2}{*}{560} & \multirow[b]{2}{*}{.34} & \multirow[b]{2}{*}{1.96} & \multirow[b]{2}{*}{0.05} & \multirow{2}{*}{$\begin{array}{l}\text { Retain null } \\
\text { hypothesis }\end{array}$} \\
\hline & State & 226 & 18.20 & 2.58 & & & & & \\
\hline \multirow{2}{*}{ Loan periods } & Federal & 336 & 31.58 & 3.45 & \multirow[b]{2}{*}{560} & \multirow[b]{2}{*}{.84} & \multirow[b]{2}{*}{1.96} & \multirow[b]{2}{*}{0.05} & \multirow{2}{*}{$\begin{array}{l}\text { Retainnull } \\
\text { hypothesis }\end{array}$} \\
\hline & State & 226 & 31.33 & 3.43 & & & & & \\
\hline \multirow{2}{*}{ Fines } & Federal & 336 & 12.86 & 1.96 & \multirow[b]{2}{*}{560} & \multirow[b]{2}{*}{.45} & \multirow[b]{2}{*}{1.96} & \multirow[b]{2}{*}{0.05} & \multirow{2}{*}{$\begin{array}{l}\text { Retain null } \\
\text { hypothesis }\end{array}$} \\
\hline & State & 226 & 12.78 & 2.09 & & & & & \\
\hline \multirow{2}{*}{ Reservation } & Federal & 336 & 12.86 & 1.96 & \multirow[b]{2}{*}{560} & \multirow[b]{2}{*}{-.54} & \multirow[b]{2}{*}{1.96} & \multirow[b]{2}{*}{0.05} & \multirow{2}{*}{$\begin{array}{l}\text { Retain null } \\
\text { hypothesis }\end{array}$} \\
\hline & State & 226 & 15.92 & 2.10 & & & & & \\
\hline
\end{tabular}

The table VIII also indicted that respondents were satisfied with policy on fines. This finding is in line with Adomi (2003) who found respondents satisfaction with fines.

The data in table VIII as well reveal general satisfaction with reservation. This finding corroborates that by
Seneviratne (2006) whose respondents were satisfied with book reservation.

Hypothesis Two: There is no significant difference between public universities in the library users' levels of satisfaction with circulation policy on library holdings.

TABLE IX Z-TEST ANALYSIS OF USERS’ LEVEL OF SATISFACTION WITH LIBRARY HOLDINGS IN PUBLIC UNIVERSITY LIBRARIES

\begin{tabular}{|c|c|c|c|c|c|c|c|c|}
\hline Institution & $\mathbf{N}$ & $\bar{X}$ & SD & Df & $\begin{array}{c}\begin{array}{c}z_{-} \text {calculated } \\
\text { value }\end{array} \\
\end{array}$ & $\begin{array}{c}z_{-} \text {critical } \\
\text { value }\end{array}$ & $\begin{array}{c}\text { Level of } \\
\text { significance }\end{array}$ & Remark \\
\hline Federal universities & 336 & 15.95 & 2.19 & \multirow[b]{2}{*}{560} & \multirow[b]{2}{*}{1.79} & \multirow[b]{2}{*}{1.96} & \multirow[b]{2}{*}{0.05} & \multirow{2}{*}{$\begin{array}{l}\text { Retain null } \\
\text { hypothesis }\end{array}$} \\
\hline State universities & 226 & 15.61 & 2.18 & & & & & \\
\hline
\end{tabular}

The data in table 1.9 show that the calculated $z$-value is 1.79 and the $z$-critical value is 1.96 at $\mathrm{df} 560$ calculated $z$-value is less than the critical $z$-value. Therefore the null hypothesis which states earlier that there is no significant difference between users' level of satisfaction with library holdings in public universities in Nigeria is retained. This finding agrees with Demekaa (2015) and Sacchelti (2011) which found that student users were satisfied with books in the collection because they are useful, and relevant to their research field.

Hypothesis Three: There is no significant difference between public universities in the library users' levels of satisfaction with circulation policy on library opening hours.

TABLE X Z-TEST ANALYSIS OF USERS’ LEVEL OF SATISFACTION WITH LIBRARY OPENING HOURS IN PUBLIC UNIVERSITIES

\begin{tabular}{|c|c|c|c|c|c|c|c|c|}
\hline Institution & $\mathbf{N}$ & $\overline{\mathrm{X}}$ & SD & Df & $\begin{array}{c}\text { z_calculated } \\
\text { value }\end{array}$ & $\begin{array}{c}\text { z-critical } \\
\text { value }\end{array}$ & $\begin{array}{c}\text { Level of } \\
\text { significance }\end{array}$ & Remark \\
\hline Federal universities & 336 & 18.67 & 2.45 & & & & & Reject null \\
State universities & 226 & 18.20 & 2.58 & 560 & -2.15 & 1.96 & 0.05 & hypothesis \\
\hline
\end{tabular}

The result presented in table $X$ shows that the calculated $\mathbf{z}$ value is -2.15 and the critical $z$-value is 1.96 at df of 560 . The calculated $\mathbf{z}$-value is greater than the critical $\mathbf{z}$-value. Therefore, the hypothesis which states that there is no significant difference between the users' level of satisfaction with library openings hours in federal and state universities is rejected. There is a significant difference between the public universities users' level of satisfaction with opening hours in university library. This finding is in line with Sharma (1994) who conducted a survey of users to know their views about library collection, timings, rules and regulations and services of Delhi Public Library Karp, Bagh.

Hypothesis Four: There is no significant difference between public universities in the library users' levels of satisfaction with circulation policy on library borrowers' cards. 
TABLE XI Z-TEST ANALYSIS OF USERS’ LEVEL OF SATISFACTION WITH LIBRARY BORROWERS’ CARDS IN PUBLIC UNIVERSITY LIBRARIES

\begin{tabular}{|c|c|c|c|c|c|c|c|c|}
\hline Institution & $\mathbf{N}$ & $\overline{\mathrm{X}}$ & SD & Df & $\begin{array}{c}\text { z_calculated }_{\text {value }} \\
\text { z_critical } \\
\text { value }\end{array}$ & $\begin{array}{c}\text { Level of } \\
\text { significance }\end{array}$ & Remark \\
\hline Federal universities & 336 & 15.84 & 1.90 & & & & & Retain null \\
State universities & 226 & 18.20 & 2.58 & 560 & .34 & 1.96 & 0.05 & hypothesis \\
\hline
\end{tabular}

The result in table XI shows that the calculated $\mathbf{z}$-value is .34 and the critical $z$-value is 1.96 at df of 560 . The calculated $\mathbf{z}$-value is less than the critical $\mathbf{z}$-value therefore the null hypothesis is retained. This implies that there is no significant difference between public universities on users' satisfaction with the library borrower's cards in university library. Just as the respondents in the study were satisfied with the total number of cards registered users are issued for borrowing of items, authors such as Edoka (1983), Lamptey (2010), and Ross (2011) have reported similarly.

Hypothesis Five: There is no significant difference between public universities in the library users' levels of satisfaction with circulation policy on library loan periods.

\begin{tabular}{|c|c|c|c|c|c|c|c|c|}
\hline Institution & $\mathbf{N}$ & $\bar{X}$ & SD & Df & $\begin{array}{c}\text { Z_calculated } \\
\text { value }\end{array}$ & $\begin{array}{c}\text { z_critical } \\
\text { value }\end{array}$ & $\begin{array}{c}\text { Level of } \\
\text { significance }\end{array}$ & Remark \\
\hline Federal universities & 336 & 31.58 & 3.45 & \multirow[b]{2}{*}{560} & \multirow{2}{*}{.84} & \multirow{2}{*}{1.96} & \multirow{2}{*}{0.05} & \multirow{2}{*}{$\begin{array}{l}\text { Retainnull } \\
\text { hypothesis }\end{array}$} \\
\hline State universities & 226 & 31.33 & 3.43 & & & & & \\
\hline
\end{tabular}

The result in table XII indicates that the calculated $z$-value is .84 and the critical $z$-value is 1.96 at df of 560. The calculated $\mathbf{z}$-value is less than the critical $\mathbf{z}$-value, therefore, the null hypothesis is retained. This indicates that there is no significant difference between public universities on users' satisfaction with library loan period in the university libraries. This finding corroborates that by Ezeala and Yusuf (2011) in which respondents were satisfied with duration of book loan period. Hypothesis Six: There is no significant difference between public universities in the library users' levels of satisfaction with circulation policy on library fines.

TABLE XIII Z-TEST ANALYSIS OF USERS' LEVEL OF SATISFACTION WITH LIBRARY FINES IN PUBLIC UNIVERSITIES

\begin{tabular}{|c|c|c|c|c|c|c|c|c|}
\hline Institution & $\mathbf{N}$ & $\bar{X}$ & SD & Df & $\begin{array}{c}\text { Z_calculated } \\
\text { value }\end{array}$ & $\begin{array}{c}\text { z_critical } \\
\text { value }\end{array}$ & $\begin{array}{c}\text { Level of } \\
\text { significance }\end{array}$ & Remark \\
\hline Federal universities & 336 & 12.86 & 1.96 & \multirow{2}{*}{560} & \multirow{2}{*}{.45} & \multirow{2}{*}{1.96} & \multirow{2}{*}{0.05} & \multirow{2}{*}{$\begin{array}{l}\text { Retain null } \\
\text { hypothesis }\end{array}$} \\
\hline State universities & 226 & 12.78 & 2.09 & & & & & \\
\hline
\end{tabular}

The result on table XIII shows that the calculated $\mathbf{z}$-value is .45 and the critical $z$-value is 1.96 at $\mathrm{df}$ of 560 . The calculated $\mathbf{z}$-value is less than the critical $\mathbf{z}$-value therefore the null hypothesis is retained. This shows that there is no significance difference between federal and state universities on users' level of satisfaction with library fines in university libraries. This finding corroborates Adomi (2003) who found respondents satisfaction with fines.

Hypothesis Seven: There is no significant difference between public universities in the library users' levels of satisfaction with circulation policy on library reservation?

TABLE XIV Z-TEST ANALYSIS OF USERS' LEVEL OF SATISFACTION WITH LIBRARY RESERVATION IN PUBLIC UNIVERSITY LIBRARIES

\begin{tabular}{|l|c|c|c|c|c|c|c|c|}
\hline Institution & $\mathbf{N}$ & $\overline{\mathrm{X}}$ & $\mathbf{S D}$ & $\mathbf{D f}$ & $\begin{array}{l}\mathbf{z}_{\text {_calculated }} \\
\text { value }\end{array}$ & $\begin{array}{l}\mathbf{z}_{\text {_c critical }} \\
\text { value }\end{array}$ & $\begin{array}{l}\text { Level of } \\
\text { significance }\end{array}$ & Remark \\
\hline Federal universities & 336 & 12.86 & 1.96 & \multirow{2}{*}{560} & -.54 & 1.96 & 0.05 & $\begin{array}{l}\text { Retain null } \\
\text { hypothesis }\end{array}$ \\
\hline State universities & 226 & 15.92 & 2.10 & & -54 & & &
\end{tabular}

The result in table XIV reveals that the calculated $\mathbf{z}$ value is -54 and the critical $\mathbf{z}$-value is 1.96 at $\mathrm{df}$ of 560 . The calculated $\mathbf{z}$-value is less than the critical $\mathbf{z}$-value therefore the null hypothesis is retained. This implies that there is no significant difference between public university libraries on users' level of satisfaction with library reservation in university library. Agboola (2000) noted that to place the items on reserve is not enough. It is necessary to determine users' reaction (level of satisfaction) to the provision and use.

\section{VI.CONCLUSION}

Based on the findings of the study, it was concluded that there is no significant difference between federal and state 
universities in users' level of satisfaction with library circulation policies on holdings, library borrowers' cards, library loan periods, library fines and library reservation. The study also showed that there was a significant difference between federal and state universities in users' level of satisfaction with library opening hours in university libraries.

\section{VII.RECOMMENDATIONS}

The following are recommended in the light of the findings:

1. The public university libraries in Nigeria should extend their opening hours on Sundays from the present $3.00 \mathrm{pm}-6.00 \mathrm{pm}$ to $3.00 \mathrm{pm}-10.00 \mathrm{pm}$ to make the users more satisfactory with the opening hours on that day.

2. The libraries should ensure that returned materials are shelved as soon as they are returned to the circulation desk. This should be spelt out in the circulation policies.

3. In order to ensure quality of users' satisfaction with circulation policies, especially with opening hours, library managers from the federal and state universities in Nigeria should explore ways of working together to improve their policies on opening hours. This can be achieved by jointly organizing workshops/seminars on circulation policies.

\section{REFERENCES}

[1] Adomi, E.E. (2003). Attitudes of university library users towards overdue fines in Nigeria. The Bottom Line: Managing Library Finances, 16(1), 1924.

[2] Adomi, E.E. (2008). Library and information service policies. Benin City: Ethiope Publishing Cooperation.

[3] Agboola, A.T. (2000). Short loan collections in Nigerian university libraries. Lagos Librarian, 21(1\&2), 46-56.

[4] Al-Fares, H.K. (1998). Optimizing a library's loan policy. An integer programming approach. Journal of American Societal for Information Science. 49(13), 1169-1176.

[5] Demekaa, U. (2015). Determinants of Users' Satisfaction with Circulation Policies of Public University Libraries in the North Central Zone Ph.D Thesis Delta State University, Abraka, Nigeria.

[6] Ezeala, L.O. \& Yusuf, E.O. (2011). Users satisfaction with library resources and services in Nigeria Agricultural Research Institute Library Philosophy and Practice. Retrieved from http://unllib.unl.edu/LPP/.

[7] Gates, T.F. (1995). A survey of circulation policies in academic fine arts libraries. Library and Information Science Research Electronic Journal (LIBRES), 5(22), 25-30.

[8] Lamptey, R.B. (2010). Promoting effective use of library resources and services at Kwame Nkrumah University of Science and Technology Library, Kumasi, Ghana.

[9] Nina-Okposung, M.O. (2011). Library policies and overdue materials in Delta State Polytechnic Libraries, Nigeria. Journal of Research in Education and Society, 2 (1), 199-207. Retrieved from http://www.icidr.org/doc/ICIDR PDF contents/journal of research in education and society

[10] Nwalo, K.I.N. (2003). Fundamentals of library practice. A manual on library routines. Ibadan: Stirling Horden Publishers.

[11] Onwioduokit, F. A. (2001). Educational research methodology and statistics, Uyo: Dorand Publishers.

[12] Ross, S. (2011). Non-resident use of public libraries in Appalachia. Library Management, 32(89), 540-551.

[13] Sacchelti, L. (2011). How to use statistics to survive a personal story. Performance Measurement and Metric, 12(1), 78-86.

[14] Seneviratne, D. (2006). Measuring user satisfaction: a case study at the PGIM branch library at Peradeniya. Journals of the University Librarians Association of Sri Lanka.

[15] Sharma, S. (1994). Users' survey of Delhi public library Karol Bagh Branch. at the PGIM branch library at Peradeniya. Journals of the University Librarians Association of Sri Lanka. Library Herald, 16(1-2), 2340. 